\title{
Ephrin Type-B Receptor 6
}

National Cancer Institute

\section{Source}

National Cancer Institute. Ephrin Type-B Receptor 6. NCI Thesaurus. Code C150225.

Ephrin type-B receptor 6 (1021 aa, $\sim 111 \mathrm{kDa}$ ) is encoded by the human EPHB6 gene.

This protein plays a role in the regulation of ephrin-B signaling pathways. 